\title{
Limnological changes in Dom Helvécio Lake (South-East Brazil): natural and anthropogenic causes
}

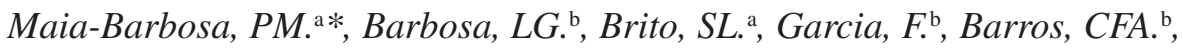 \\ Souza, MBG. ${ }^{\mathrm{b}}$, Mello, $N .^{\mathrm{a}}$, Guimarães, AS. ${ }^{\mathrm{a}}$ and Barbosa, FAR. ${ }^{\mathrm{b}}$ \\ áLaboratório de Ecologia do Zooplâncton, Instituto de Ciências Biológicas, \\ Universidade Federal de Minas Gerais - UFMG, Av. Antônio Carlos, 6627, \\ CP 486, CEP 30161-970, Belo Horizonte, MG, Brazil
}

${ }^{\text {b} L a b o r a t o ́ r i o ~ d e ~ L i m n o l o g i a, ~ I n s t i t u t o ~ d e ~ C i e ̂ n c i a s ~ B i o l o ́ g i c a s, ~ U n i v e r s i d a d e ~ F e d e r a l ~ d e ~ M i n a s ~ G e r a i s ~-~ U F M G, ~}$

Av. Antônio Carlos, 6627, CP 486, CEP 30161-970, Belo Horizonte, MG, Brazil

*e-mail: maia@icb.ufmg.br

Received January 08, 2010 - Accepted June 05, 2010 - Distributed October 31, 2010

(With 8 figures)

\begin{abstract}
In order to verify changes in physical, chemical and biological features of Dom Helvécio Lake (South-East Brazil), this study compares previous and recent data obtained from limnological investigations over three decades. Plankton species composition and density together with environmental data from 1978, 1983, and during 1999 to 2006 showed changes driven by seasonal climatic forces or by anthropogenic causes. Changes in diversity are shown as a consequence of alternation of rainy and dry periods and introduction of exotic fish species. Finally, suggestions are made for improving conservation efforts in the area, through planned actions and monitoring programmes.
\end{abstract}

Keywords: tropical lake, long term studies, trophic changes, phytoplankton, zooplankton.

\section{Mudanças limnológicas no lago Dom Helvécio (Sudeste Brasil): causas naturais e antropogênicas}

\section{Resumo}

Com o objetivo de avaliar as mudanças nas características físicas, químicas e biológicas do lago Dom Helvécio (Sudeste do Brasil), este estudo compara dados anteriores e recentes de investigações limnológicas através de três décadas. A composição e a densidade das espécies planctônicas juntamente com os dados ambientais apresentaram mudanças decorrentes de forças climáticas e de causas antropogênicas. Mudanças na diversidade como consequência da sazonalidade e da introdução de espécies exóticas de peixes foram observadas. Com base nos resultados, são feitas sugestões para aumentar os esforços de conservação na área através de ações planejadas e programas de monitoramento.

Palavras-chave: lago tropical, estudos de longa duração, alterações tróficas, fitoplâncton, zooplâncton.

\section{Introduction}

Limnological research in the Rio Doce State Park (south-east Brazil) started in 1976 and the first descriptive studies already demonstrated the importance of this area for the understanding of the functioning mechanisms of tropical lakes, namely patterns of thermal stratification, levels of primary production, contribution of alloctonous material and nutrient cycling (e.g. Barbosa and Tundisi, 1980). Following this, scientific investigations in the middle Rio Doce basin increased remarkably with the launching of the Long Term Ecological Research Program (LTER-Brazil site \# 4) in 1999, when the middle Rio Doce basin lakes, in general, started to be regularly sampled. In the LTER-Brazil Technical Reports from 2000 to 2006, Barbosa and Padisak (2002), Maia-Barbosa et al. (2003),
Barros et al. (2006), Maia-Barbosa et al. (2006) presented some results of this study.

Dom Helvécio Lake is the deepest natural lake in Brazil and has been the focus of research since the late 70 's. Early research represents a necessary reference for any consideration over its conservation status as it is the only historic testimony of its evolution, because no information contained in the sediments has yet been analysed. Accordingly, the information collected over the past two decades can give indications about relatively short-term responses regarding, specially, the qualitative and quantitative composition of phyto- and zooplankton populations, which are the main groups studied within the LTER. 
Interestingly, and despite being located within a conservation unit (Rio Doce State Park) impacts were detected in some lakes from which introduction of exotic fish species and tourism pressure deserve special attention, particularly when studying Dom Helvécio Lake (Latini et al., 2004). These impacts can change species abundance, ecosystem functioning and have economic effects through reduction of ecosystem goods and services to society (Chapin III et al., 2000).

In order to verify changes in physical, chemical and biological features of Dom Helvécio Lake, this study compares previous and recent data obtained from limnological investigation over three decades. The recent period of research, from 1999 to 2006, has been set apart for its larger regularity of sampling, and primarily by the boost on sensitivity and specificity of gathered information concerning all aspects of the limnology of the lake. Considering this, an effort was made to validate the influence of distinct factors over time to explain the current trophic status of Dom Helvécio Lake.

\section{Material and Methods}

\subsection{Study site}

Dom Helvécio Lake (1946'56.7” S and 42 35' 29.1” W) has a dendritic shape with $6.87 \mathrm{~km}^{2}$ surface area, maximum depth of $39.2 \mathrm{~m}$ (Bezerra-Neto and Pinto-Coelho, 2008), and mean depth of $11.3 \mathrm{~m}$ (Figure 1), being a warm-monomictic lake with circulation period from May until August. Over a 24 hours time scale, its atelomictic conditions were also demonstrated (Barbosa and Padisak, 2002). Records of exotic fish species introductions are dated since 1979 (Pygocentrus nattereri Block and Schneider, Astronotus ocellatus Agassiz, and Cychla kelberi Kner) (Godinho and Formagio, 1992). It has been open to the public since the mid 80's particularly allowing for aquatic sports such as fishing and swimming at its shore line together with camping activities at one particular spot, called the "beach". Situated within the middle Rio Doce basin (Minas Gerais State, Brazil), local climate is tropical semi-humid with average temperatures around $25^{\circ} \mathrm{C}$ and with 4-5 months

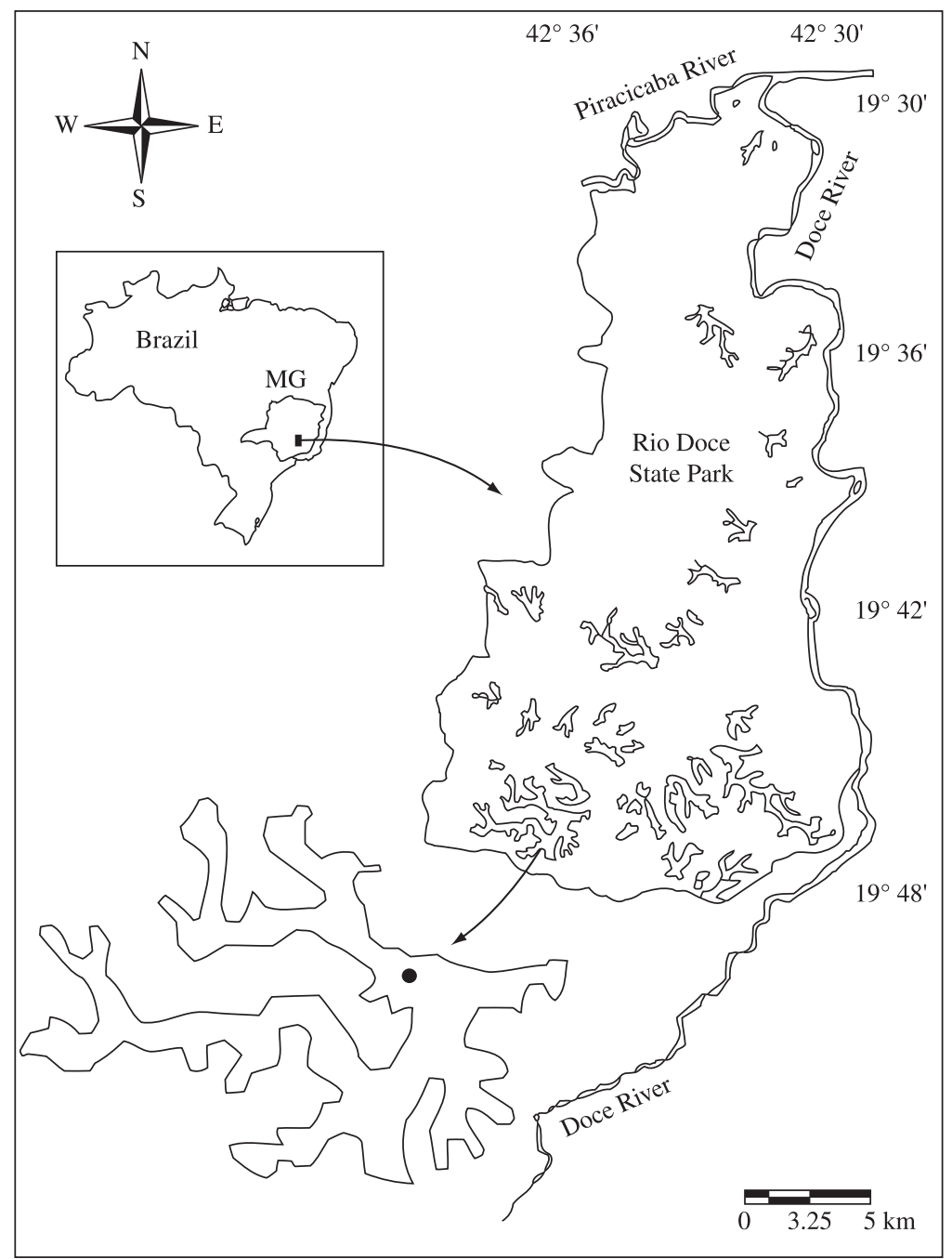

Figure 1. Location and map of Dom Helvécio Lake, Rio Doce State Park, Minas Gerais, Brazil. 
of dryness when temperatures around $18^{\circ} \mathrm{C}$ characterise the coldest months (Tundisi, 1997).

\subsection{Environmental data}

Data from the 70's and the 80's were obtained from the literature and more recent data (1999-2006) were recorded by LTER. The specific sampling periods, depths, and methods used for nutrients and plankton analysis are summarised in Table 1. Percentage of incident light was estimated according to measurements with a Secchi disk (Cole, 1983). Temperature, electric conductivity, chlorophyll- $a$ and nutrient concentrations (total phosphorus, total nitrogen, ammonium-nitrogen), and the structure and composition of planktonic communities (phyto and zooplankton) from all databases were considered. The trophic status of Dom Helvécio Lake was calculated according to the index of Carlson (1977) adopting the modifications by Toledo et al. (1983).

Data do not exhibit normal distribution, so structure and variability in the final set were evaluated using non-parametric analysis. Differences among years were assessed by the Kruskal-Wallis test and between dry and rainy periods by the Mann-Whittney U-test (two sided).

\section{Results}

\subsection{Changes within the physical and chemical environment}

Reduction (50-75\%) of euphotic zone was recorded during the period from 1978 to 2006 through Secchi disk measurement changes (Figure 2). Increase in temperature within the upper layers was evident: $24-25^{\circ} \mathrm{C}$ in 2000 to 29-31 ${ }^{\circ} \mathrm{C}$ from 2002 onwards, likely to be a direct effect of the ENSO (El Niño) event in 2002, when the lake did not exhibit total mixing of the water column (Figure 3 ). Increase in phosphorus and nitrogen concentrations, and conductivity were observed specially between 1978 and 2006 ( $p>0.05$ ). Total phosphorus varied from 0.07 to $6.1 \mu \mathrm{mol} . \mathrm{L}^{-1}$; total nitrogen from $4.9 \mu \mathrm{mol} . \mathrm{L}^{-1}$ in 1985 to $193.4 \mu \mathrm{mol} . \mathrm{L}^{-1}$ in 2006 , and chlorophyll- $a$ from $2.0 \mu \mathrm{g} . \mathrm{L}^{-1}$ in 1985 to $15.0 \mu \mathrm{g} . \mathrm{L}^{-1}$ (average value between 1999 to 2006) reaching peaks of c.30 $\mu \mathrm{g} . \mathrm{L}^{-1}$ in 2002 and 2006, suggesting an increase of the trophic status of the lake. This eutrophication is also indicated by the levels of ammonium-nitrogen which changed from $0.04 \mu \mathrm{mol} . \mathrm{L}^{-1}$ in 1985 to $80.3 \mu \mathrm{mol} . \mathrm{L}^{-1}$ in 2006 and conductivity values that changed from $31.3 \mu \mathrm{S} . \mathrm{cm}^{-1}$ in 1978 to $52.0 \mu \mathrm{S} . \mathrm{cm}^{-1}$ in 2006 (Figures 4 to 8). These increases were responsible for the change of the trophic status from oligotrophic to

Table 1. Summary of sampling periods, depths, and methods used for nutrient and plankton analysis of limnological studies in Dom Helvécio Lake (South-East Brazil), from 1978 to 2006.

\begin{tabular}{|c|c|c|c|c|c|c|}
\hline Data & $\begin{array}{c}\text { Forte-Pontes } \\
(1980)\end{array}$ & $\begin{array}{l}\text { Santos } \\
(1980)\end{array}$ & $\begin{array}{l}\text { Okano } \\
(1980)\end{array}$ & $\begin{array}{l}\text { Matsumura- } \\
\text { Tundisi (1997) }\end{array}$ & $\begin{array}{c}\text { Mitamura \& } \\
\text { Hino (1997) }\end{array}$ & $\begin{array}{c}\text { LTER-Brazil } \\
\text { site \#4 }\end{array}$ \\
\hline Period & $\begin{array}{c}\text { July/1977; } \\
\text { Jan. and July/1978 }\end{array}$ & $\begin{array}{l}\text { July/1977; } \\
\text { Jan. and } \\
\text { July/1978 }\end{array}$ & 1978 & July/1983 & $\begin{array}{l}\text { Nov.-Dec./1985 } \\
\text { and } \\
\text { June-July/1987 }\end{array}$ & $\begin{array}{c}\text { Seasonal } \\
\text { sampling 1999- } \\
\text { 2000; monthly } \\
\text { sampling } \\
\text { 2001-2006 }\end{array}$ \\
\hline Depths & $\begin{array}{c}\text { July/1977 } \\
\text { (1; 3; 5; 10; 15; 20; } 28 \mathrm{~m}) \\
\text { Jan./July } 1978 \\
\text { (100; 50; 25;10; } 1 \% \\
\text { of incident light (Secchi), } \\
\text { and } 20 ; 25 \mathrm{~m})\end{array}$ & $\begin{array}{c}\text { Surface, } \\
\text { intermediate } \\
\text { and deep waters }\end{array}$ & $\begin{array}{l}\text { Every } 5 \mathrm{~m} \\
\text { until } 25 \mathrm{~m}\end{array}$ & $\begin{array}{l}2 ; 5 ; 10 ; 15 ; \\
20 ; 25 ; 30 \mathrm{~m}\end{array}$ & $\begin{array}{c}2 ; 5 ; 10 ; 15 ; 20 ; \\
25 ; 30 \mathrm{~m}\end{array}$ & $\begin{array}{c}100 ; 15 ; 1 \% \text { of } \\
\text { incident light } \\
\text { and aphotic zone } \\
\text { (Secchi) }\end{array}$ \\
\hline Total-P & Golterman et al. (1978) & $\begin{array}{l}\text { Golterman et al. } \\
\text { (1978) at } 15 \mathrm{~m}\end{array}$ & - & - & - & $\begin{array}{l}\text { Mackereth et al. } \\
\text { (1978) }\end{array}$ \\
\hline Total-N & - & - & - & - & - & $\begin{array}{l}\text { Mackereth et al. } \\
\text { (1978) }\end{array}$ \\
\hline $\mathrm{N}-\mathrm{NH}_{4}$ & - & - & - & Sagi (1966) & Sagi (1966) & Koroleff (1976) \\
\hline Chlorophyll- $a$ & $\begin{array}{c}\text { Chlorophyll and } \\
\text { pheophytin Golterman } \\
\text { et al. (1978) }\end{array}$ & $\begin{array}{c}\text { Chlorophyll } \\
\text { and pheophytin } \\
\text { Golterman et al. } \\
\text { (1978) }\end{array}$ & - & - & $\begin{array}{c}\text { SCOR/Unesco } \\
(1966)\end{array}$ & $\begin{array}{c}\text { Chlorophyll } \\
\text { and pheophytin } \\
\text { Lorenzen (1967) }\end{array}$ \\
\hline Phytoplankton & van Dorn sampler & - & - & - & - & van Dorn sampler \\
\hline Zooplankton & - & - & $\begin{array}{l}\text { Water pump } \\
\qquad(200 \mathrm{~L} ; \\
68 \mu \mathrm{m} \text { net })\end{array}$ & $\begin{array}{l}\text { Water pump } \\
\qquad(400 \mathrm{~L} ; \\
68 \mu \mathrm{m} \text { net })\end{array}$ & - & $\begin{array}{l}\text { 1999-2002 van } \\
\text { Dorn sampler; } \\
\text { 2003-2006 } \\
\text { water pump } \\
(200 \mathrm{~L} ; \\
60 \mu \mathrm{m} \text { net })\end{array}$ \\
\hline
\end{tabular}




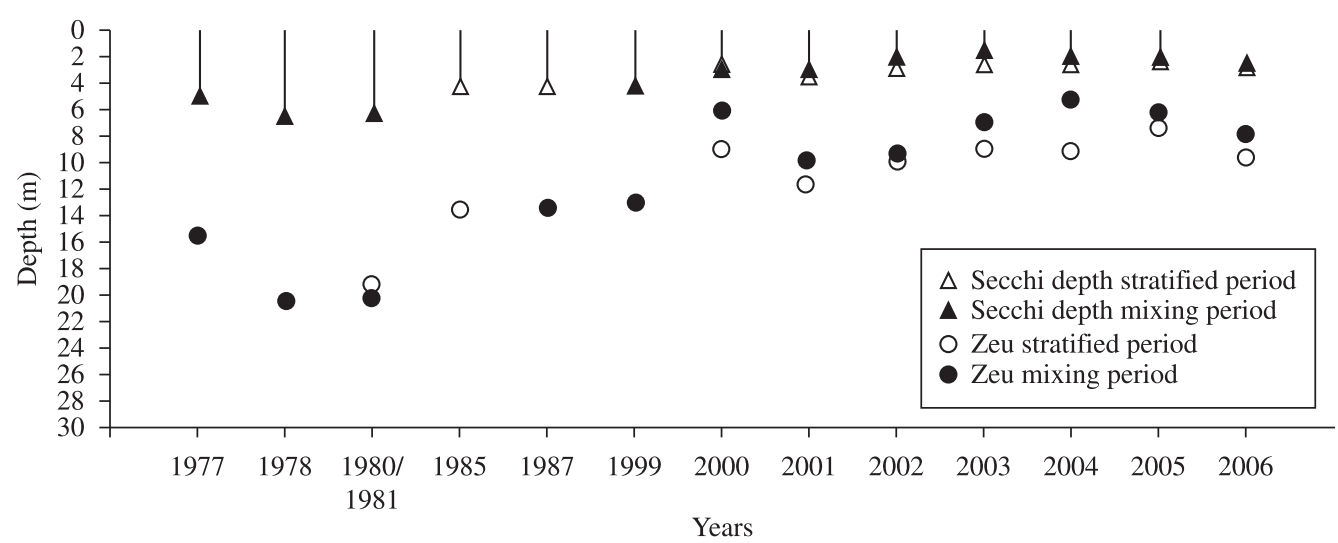

Figure 2. Secchi depths and euphotic zone of Dom Helvécio Lake (Minas Gerais, South-East Brazil) during the years 1977, $1978,1985,1987$, and from 1999 to 2006.

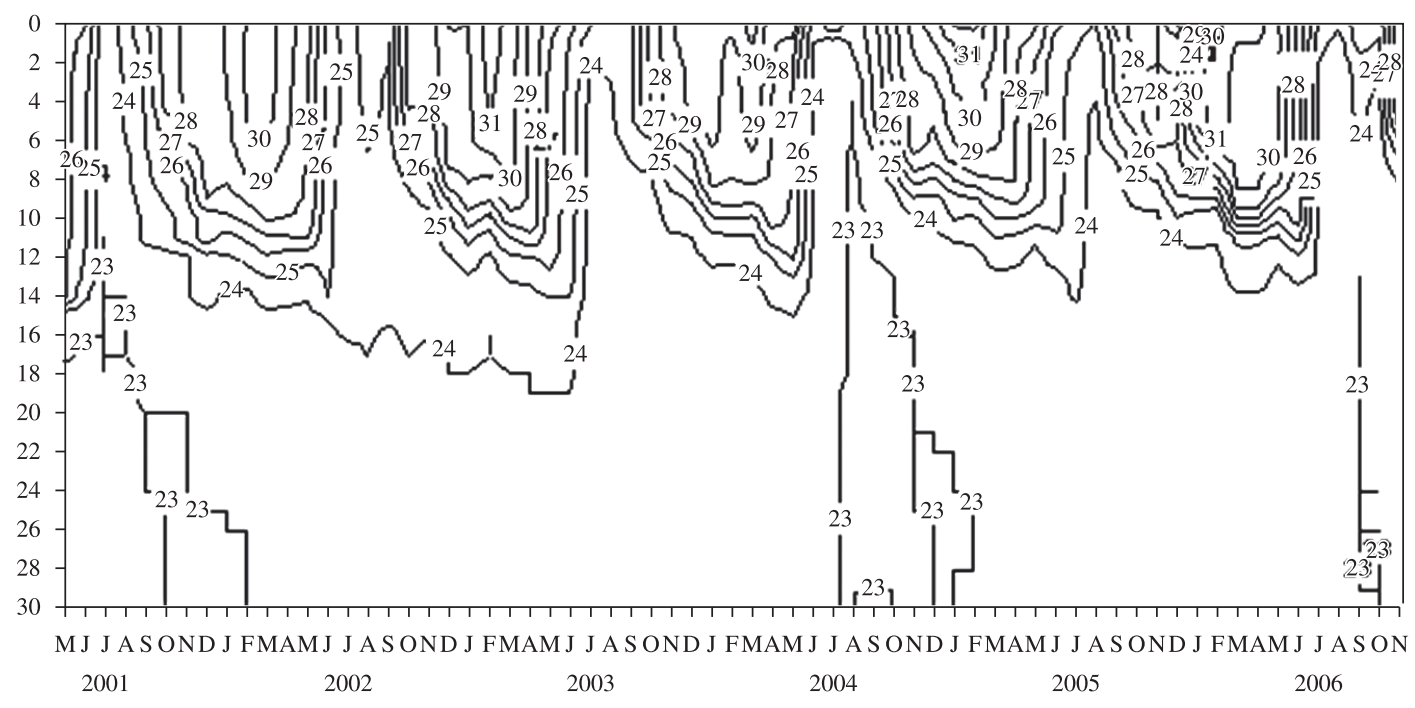

Figure 3. Depth-time diagram of the water temperature $\left({ }^{\circ} \mathrm{C}\right)$ in Dom Helvécio Lake (Minas Gerais, South-East Brazil) from May 2001 to December 2006.

oligo-mesotrophic according to the Carlson index (1977 modified by Toledo et al., 1983).

\subsection{Major changes within plankton communities}

Following intensification of samplings that started in 1999, 81 new phytoplankton taxa were recorded summing up 153 species in this lake, so far. In 1978, two Classes alternated in dominance (mentioned here as relative abundance): Chrysophyceae (maximum of $70.2 \%$ in January and minimum of $7.6 \%$ in June) together with Cryptophyceae (maximum of $52.8 \%$ in July and minimum of $2.5 \%$ in January). From 1999 onwards, a clear replacement of these two classes by Zygnemaphyceae (desmids, mainly, Cosmarium and Staurastrum) was recorded and filamentous Cyanobacteria during stratification periods and by Cyanobacteria and Chlorophyceae during the mixing one. Higher densities were recorded during stratification periods $\left(18 \times 10^{3}\right.$ org. $\mathrm{mL}^{-1}$ in 2000 and $13 \times 10^{3}$ org. $\mathrm{mL}^{-1}$ in 2002) than in mixing ones.

Zooplankton community within the limnetic region is composed of 73 taxa while within the littoral zone this community is larger, there existing $c .30$ new species for this lake (Maia-Barbosa et al., 2008). Considering only the limnetic zooplankton, Rotifera is represented by 51 species, Cladocera by 17 species, and Copepoda by 5 species. This general composition is distinct from the one recorded by Matsumura-Tundisi and Okano (1983) when Copepoda and Cladocera were represented by 5 species each, and Rotifera were composed only of 4 species.

Replacing Scolodiaptomus corderoi Wright and Argyrodiaptomus furcatus Sars as dominant species, Thermocyclops minutus Lowndes (Cyclopoida) can currently represent up to $75 \%$ of the total zooplankton density at Dom Helvécio Lake (e.g. May 2002). Other Copepoda (Microcyclops anceps Richard and Notodiaptomus 


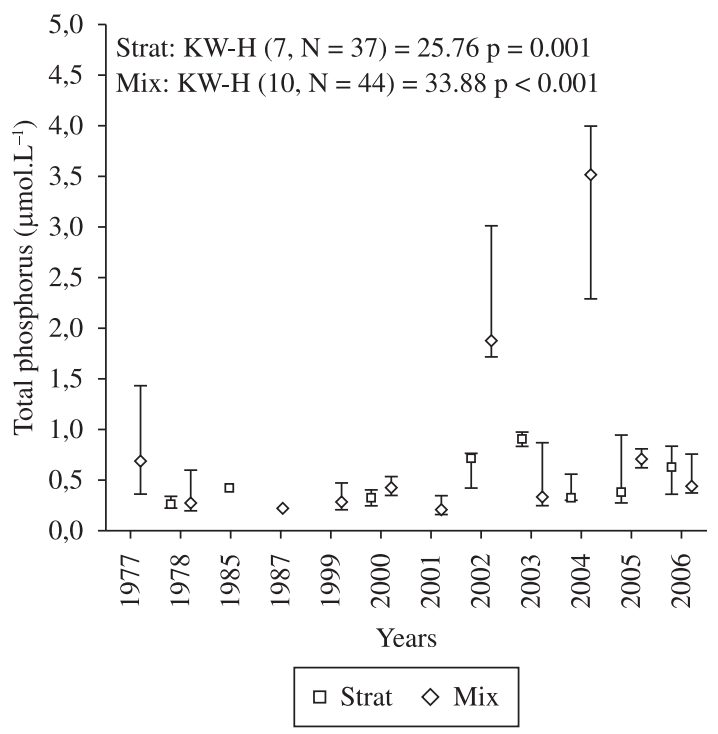

Figure 4. Total Phosphorus concentration values (median, minimum, and maximum, $\mu$ mol. $\mathrm{L}^{-1}$ ) in Dom Helvécio Lake (Minas Gerais, South-East Brazil) during the years 1977, 1978, 1985, 1987 and from 1999 to 2006.

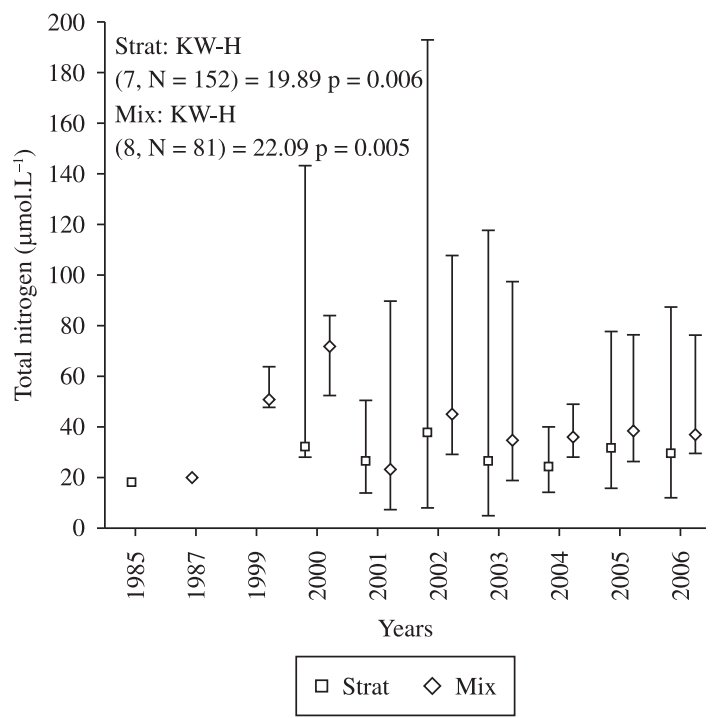

Figure 5. Total Nitrogen concentration values (median, minimum, and maximum, $\mu \mathrm{mol} . \mathrm{L}^{-1}$ ) in Dom Helvécio Lake (Minas Gerais, South-East Brazil) during the years 1985, 1987 and from 1999 to 2006.

isabellae Wright) have sporadic occurrence and rarely surpass $1 \%$ of the total zooplankton density. Contribution of Cladocera has been small, and their relative abundance rarely surpasses 5\%. Among Rotifera predominant genera are Ptygura, Hexarthra and Brachionus.

\section{Discussion}

Although located within a conservation unit, Dom Helvécio Lake has been going through considerable changes

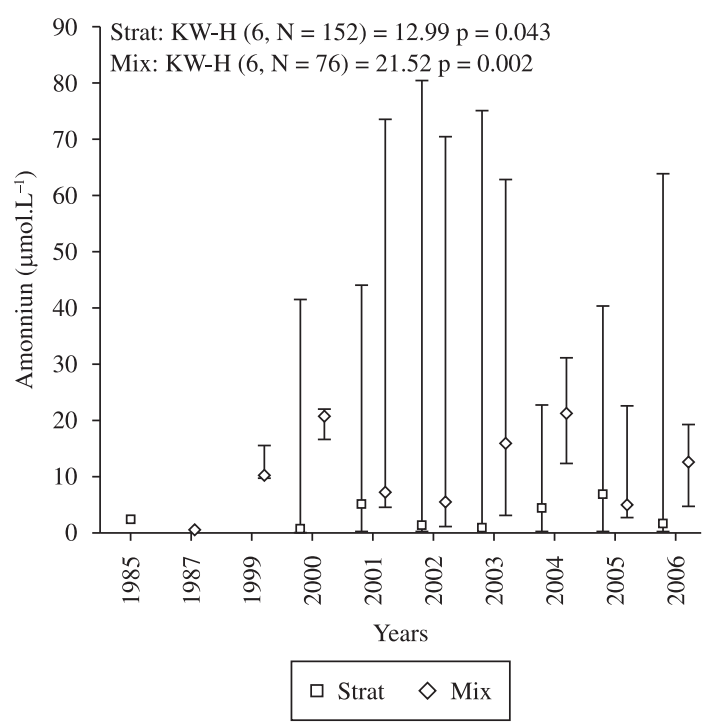

Figure 6. Ammonium-Nitrogen concentration values (median, minimum, and maximum, $\mu \mathrm{mol} . \mathrm{L}^{-1}$ ) in Dom Helvécio Lake (Minas Gerais, South-East Brazil) during the years 1985, 1987 and from 1999 to 2006.

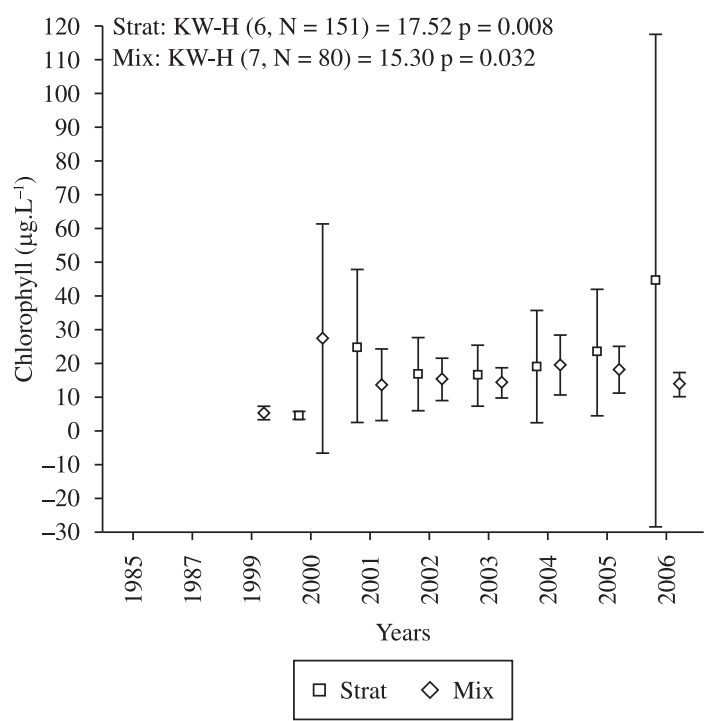

Figure 7. Chlorophyll- $a$ values (median, minimum and maximum, $\mu$ mol. $\mathrm{L}^{-1}$ ) in Dom Helvécio Lake (Minas Gerais, South-East Brazil) during the years 1985, 1987, and from 1999 to 2006.

during the last three decades, both in its physical-chemical matrix as well as in its biological one, and response of planktonic group is evident.

Reduction of the euphotic zone, increase in nutrient loads and chlorophyll- $a$ concentrations are likely to result in changes in its trophic status as indicated by the oligomesotrophic conditions according to the Carlson index and such change might be already indicated through replacement of phytoplankton assemblages associated 


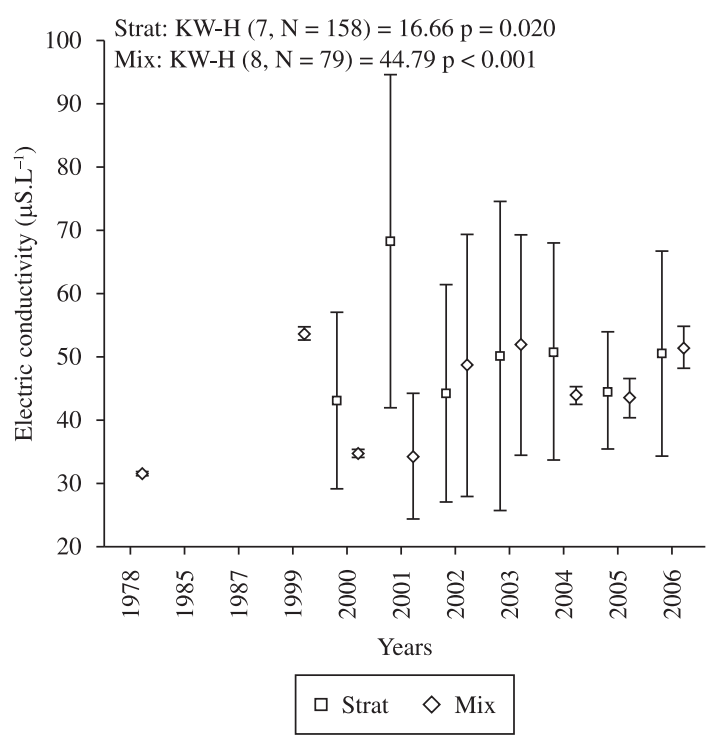

Figure 8. Electric conductivity values (median, minimum and maximum, $\mu \mathrm{S} . \mathrm{cm}^{-1}$ ) in Dom Helvécio Lake (Minas Gerais, South-East Brazil) during the year 1978, and from 1999 to 2006.

with higher trophic status, like the regular accounts of Cyanobacteria dominated ones (Reynolds, 1997).

Moreover, maximal densities of phytoplankton in Dom Helvécio Lake are often registered during stratification periods when desmids dominate within the upper layers and Cyanobacteria are more abundant within the lower ones. Such structure is maintained due to the onset of atelomictic conditions which provide enough turbulence to keep small desmids within the photic zone as demonstrated by Barbosa and Padisák (2002) and Souza et al. (2008). This vertical distribution has changed, however, by frequent reports in recent years (unpublished data), of Microcystis blooms in Dom Helvécio Lake, lending more support to the anticipation of its trophic status change.

One of the major conclusions of comparative studies conducted by Tundisi et al. (1981) in the middle Rio Doce basin lakes combining morphometry, chemical and biological characteristics resulted in a series of oligo-eutrophy in the following sequence of lakes: Dom Helvécio < Bonita < Carioca < Belgo Mineira < “33". Dom Helvécio Lake was considered oligo-mesotrophofic when judged by its phytoplankton assemblages (Reynolds, 1997). Matsumura-Tundisi (1997) considered dominance of Calanoid copepods over Cyclopoida and low densities of rotifers and cladocerans as indicators of oligotrophy, previously demonstrated by Gannon and Stemberger (1978). However, our results (nutrients, chlorophyll- $a$, phyto- and zooplankton densities and composition) suggest present mesotrophic conditions for Dom Helvécio Lake. Moreover, among the zooplankton, the dominant species (Scolodiaptomus corderoi and Argyrodiaptomus furcatus) have been replaced by Thermocyclops minutus (Maia-
Barbosa et al., 2003) and the total number of species increased from 14 in 1983 to 73 in 2006, being Copepoda mostly Cyclopoida the dominant group in terms of density and Rotifera in number of species. According to Rietzler et al. (2002) A. furcatus is well adapted to oligotrophic conditions and can ingest algae of varied size. Replacing an herbivorous zooplankton (Calanoida) by an omnivorous one (Cyclopoida) implies lower herbivory pressure on the phytoplankton (Matsumura-Tundisi et al., 1997; Work and Havens, 2003). This change also might have contributed to increasing chlorophyll- $a$ concentrations, occurrence of periods dominated by Cyanobacteria, blooms of Microcystis spp and the establishment of Cylindrospermopsis raciborskii (Woloszynska) Seenayya and Subba Raju.

Studies conducted during the 1970's at Dom Helvécio Lake demonstrated a relatively small contribution of nauplii (19.1\%) for the zooplankton community, calling attention to the predominance of copepodites and adults, a situation normally not fond in the majority of aquatic ecosystems. The present data demonstrated that the zooplankton community has gone through considerable changes as suggested by the replacement of Scolodiaptomus corderoi by Thermocyclops minutus demonstrated by Maia-Barbosa et al. (2003). Furthermore, it is likely that changes within the phytoplankton community such as the predominance of filaments of Cylindrospermopsis raciborskii could be a limiting factor for ingestion by specialised filter-feeding copepods such as Calanoida and also another possible reason for their replacement.

Richness of native fish species showed reduction between 1983 and 1992, and five species disappeared. In addition, remnant species showed reduced densities and a constraint recruitment process. These changes are attributed to the introduction of Pygocentrus nattereri and Cichla kelberi, predator species exhibiting high abundances in the lake ( $75 \%$ of total abundance) according to Godinho et al. (1994).

One of the most important consequences of exotic fish introductions is the disappearance of foraging fish species such as Astyanax bimaculatus Linneaus and A. faciatus Cuvier, which were main species in controlling densities of high plankton predator species such as Chaoboridae larvae. Currently, because the controlling fish species are no longer effective, Chaoborus is the top predator for plankton communities, and very abundant, verified by the large numbers of exuviae in Dom Helvécio Lake surface at the onset of stratification conditions.

\subsection{Some perspectives for the deepest natural lake in Brazil}

Changes in its abiotic matrix and plankton composition, specially after reduction of fish diversity, give clear insights into noteworthy alterations in the trophic chain of Dom Helvécio Lake. This study emphasises the importance of long-term monitoring programmes for identification of changes in the entire ecosystem and for providing new information essential for management strategies and biodiversity conservation. Judging by the expected 
increase of tourists in the area, decrease in water quality is likely to happen, a tendency already seen during recent years. This information is of paramount importance for the definition and implementation of public policies such as better control of tourism activities in the lake area, that can be performed particularly with the community surrounding the State Park, for which environmental education activities are already being conducted.

Acknowledgements - The authors are grateful to colleagues of the Biological Sciences Institute for their contributions throughout the project's development. The research was funded by CNPq (Process 520031/98-9), through the Brazilian LTER project, site \# 4.

\section{References}

BARBOSA, FAR. and PADISÁK, J., 2002. The forgotten lake stratification pattern: atelomixis, and its ecological importance. Verhandlungen der Internationalen Vereinigung fur Theoretische und Angewandte Limnologie, vol. 28, p. 1385-1395.

BARBOSA, FAR. and TUNDISI, JG., 1980. Primary production of phytoplankton and environmental characteristics of a shallow Quarternary lake at Eastern Brasil. Archive für Hydrobiologie, vol. 90 , no. 2, p. 139-161.

BARROS, CFA., SOUZA, MBG. and BARBOSA, FAR., 2006. Seasonal mechanisms driving phytoplankton size structure in a tropical deep lake (Dom Helvécio Lake, South-East Brazil). Acta Limnologica Brasiliensia, vol. 18, no. 1, p. 55-66.

BEZERRA-NETO, JF. and PINTO-COELHO, RM., 2008. Morphometric study of Lake Dom Helvécio, Parque Estadual do Rio Doce (PERD), Minas Gerais, Brazil: a re-evaluation. Acta Limnologica Brasiliensia, vol. 20, no. 2, p. 161-167.

CARLSON, RE. 1977. A trophic state index for lakes. Limnology and Oceanography, vol. 22, p. 361-369.

CHAPIN III, FS., ZAVALETA, ES., EVINER, VT., NAYLOR, RL., VITOUSEK, PM., REYNOLDS, HL., HOOPER, DU., LAVOREL, S., SALA, OE., S. HOBBIE, E., MACK, MC. and DÍAZ. S. 2000. Consequences of changing biodiversity. Nature, vol. 405, p. 234-242.

COLE, GA. 1983. Textbook of Limnology. St. Louis: The C.V. Mosby Company. $401 \mathrm{p}$.

FORTE-PONTES, MC. 1980. Produção primária, fitoplâncton e fatores ambientais no lago Dom Helvécio, Parque Florestal do Rio Doce/MG. São Carlos: Universidade Federal de São Carlos. 293p. [Dissertação de Mestrado].

GANNON, JE. and STEMBERGER, R. 1978. Zooplankton (especially crustaceans and rotifers) as indicators of water quality. Transactions of the American Microscopical Society, vol. 97 , p. 16-35.

GODINHO, AL., FONSECA, MT. and ARAÚJO, LM. 1994. The ecology of predator fish introductions: the case of Rio Doce Valley Lakes. In COELHO, RMP., GIANI, A., SPERLING, E., (Eds). Ecology and human impact in lakes and reservoirs in Minas Gerais with special reference to future development and management strategies. Belo Horizonte: SEGRAC. 193 p.

GODINHO, AL. and FORMAGIO, PS. 1992. Efeitos da introdução de peixes Cichla ocellaris e Pygocentrus sp sobre a comunidade de peixes da lagoa Dom Helvécio, MG.In Encontro Anual de Aquicultura de Minas Gerais. Belo Horinzonte: AMA. p. 93-102.

GOLTERMAN, HL., CLYMO, RS. and OHNSTAD, MAM. 1978. Methods for physical and chemical analysis of freshwaters. Oxford: Blackwell Scientific Publications. 166 p.

KOROLEFF, F., 1976. Determination of ammonia. In GRASSHOFF, K. (ed.). Methods of seawater analysis. Verlag Chemie: Weinheim. $632 \mathrm{p}$.

LATINI, AO., LIMA-Jr., DP., GIACOMINI, HC., LATINI, RO., RESENDE, DC., ESPÍRITO-SANTO, HMV., BARROS, DF. and PEREIRA, TL., 2004. Alien fishes in lakes of the Doce river basin (Brazil): range, new occurrences and conservation of native communities. Lundiana, vol. 5, no. 2, p. 135-142.

LORENZEN, CJ. 1967. Determination of chlorophyll and phaeopigments: spectrophotometric equations. Limnology and Oceanography, vol. 12, p. 343-346.

MACKERETH, FJH., HERON, J. and TALLING, JF. 1978. Water analysis and some revised methods for limnologists. New York: Freshwater Biological Association. 120 p.

MAIA-BARBOSA, PM., ESKINAZI-SANT'ANNA, EM. and BARBOSA, FAR. 2003. Zooplankton composition and vertical distribution in a tropical, monomictic lake (Dom Helvécio lake, Southeastern Brazil). Acta Limnologica Brasiliensia, vol. 15, p. 65-74.

MAIA-BARBOSA, PM., BARROS, CFA., SOUZA, MBG., FARIA, VR., BARBOSA, LG., BRITO, SL., SOUZA, RA., RIETZLER, A., ESKINAZI SANT'ANNA, E. and BARBOSA, FAR., 2006. The middle Rio Doce lakes, southeast Brazil: biodiversity and its controlling forces at local and regional scales. Verhandlungen der Internationalen Vereinigung fur Theoretische und Angewandte Limnologie, vol. 29, p. 1-5.

MAIA-BARBOSA, PM., PEIXOTO, RS. and GUIMARÃES, AS., 2008. Zooplankton in littoral waters of a tropical lake: a revisited biodiversity. Brazilian Journal of Biology, vol. 68, no. 4, p. 1069-1078.

MATSUMURA-TUNDISI, T., 1997. Composition and vertical distribution of zooplankton in Lake Dom Helvécio. In TUNDISI, JG. and SAIJO, Y. (eds). Limnological Studies on the Rio Doce Valley Lakes, Brazil. São Paulo: Brazilian Academy of Sciences. $513 \mathrm{p}$.

MATSUMURA-TUNDISI, T. and OKANO, W. 1983. Seasonal fluctuations of copepod populations in lake Dom Helvécio (Parque Florestal, Rio Doce, Minas Gerais, Brazil). Revista Hydrobiologia Tropical, vol. 16, p. 35-39.

MATSUMURA-TUNDISI, T., ROCHA, O. and TUNDISI, JG., 1997. Carbon uptake by Scolodiaptomus corderoi and Thermocyclops minutus feeding on different size fractions of phytoplankton from lake Dom Helvécio. In TUNDISI, JG. and SAIJO, Y. (eds). Limnological Studies on the Rio Doce Valley Lakes, Brazil. São Paulo: Brazilian Academy of Sciences. 513 p.

MITAMURA, O. and HINO, K. 1977. Distribution of Biogeochemical Constituents in the waters. In TUNDISI, JG. and SAIJO, Y. (eds). Limnological Studies on the Rio Doce Valley Lakes, Brazil. São Paulo: Brazilian Academy of Sciences. 513 p.

OKANO, WY. 1980. Padrão de migração vertical e flutuação sazonal das principais espécies de Copepoda (Crustacea) do lago Dom Helvécio: Parque Estadual do Rio Doce-MG. São Carlos: Universidade Federal de São Carlos. 168 p. [Dissertação de Mestrado]. 
REYNOLDS, CS. 1997. On the vertical distribution of phytoplankton in the middle Rio Doce Valley lakes. In TUNDISI, JG. and SAIJO, Y. (eds). Limnological Studies on the Rio Doce Valley Lakes, Brazil. São Paulo: Brazilian Academy of Sciences. 513 p.

RIETZLER, AC., MATSUMURA-TUNDISI, T. and TUNDISI, JG. 2002. Life cycle, feeding and adaptive strategy implications on the co-occurrence of Argyrodiaptomus furcatus and Notodiaptomus iheringi in Lobo-Broa Reservoir (SP, Brazil). Brazilian Journal of Biology, vol. 62, p. 93-105.

SAGI, T., 1966. Determination of ammonia in sea water by the indophenol method and its application to the coastal and off-shore waters. The Oceanography Magazine, vol. 18, p. 43-51.

SANTOS, LC., 1980. Estudo das populações de Cladocera em cinco lagos naturais (Parque Estadual do Rio Doce-MG), que se encontram em diferentes estágios de evolução. São Carlos: Universidade Federal de São Carlos. 260 p. [Dissertação de Mestrado].

SOUZA, MBG., BARROS, CFA., BARBOSA F., HAJINAL, E. and PADISÁK, J. 2008. Role of atelomixis in phytoplankton assemblages' replacement in Dom Helvécio Lake, South-East Brazil. Hydrobiologia, vol. 607, p. 211-224.

TOLEDO, A., TALARICO, M., CHINEZ, SJ., and AGUDO, EG. 1983. A aplicação de modelos simplificados para a avaliação do processo de eutrofização em lagos e reservatórios tropicais. In Anais do 12 Congresso Brasileiro de Engenharia Sanitária e Ambiental. Camboriú. p. 1-34.

TUNDISI, JG., 1997. Climate. In TUNDISI, JG. and SAIJO, Y. (eds). Limnological Studies on the Rio Doce Valley Lakes, Brazil. São Paulo: Brazilian Academy of Sciences. 513 p.

TUNDISI, J. G, MATSUMURA-TUNDISI, T., FORTE PONTES, M.C. and GENTIL, J.G. 1981. Limnological studies of quaternary lakes in eastern Brazil. I Primary production of phytoplankton and ecological factors at Lake Dom Helvécio. Revista Brasileira de Biologia = Brazilian Journal of Biology, vol. 4, p. 5-14.

WORK, KA. and HAVENS, KE. 2003. Zooplankton grazing on bacteria and cyanobacteria in a eutrophic lake. Journal of Plankton Research, vol. 25, p. 1301-1307. 